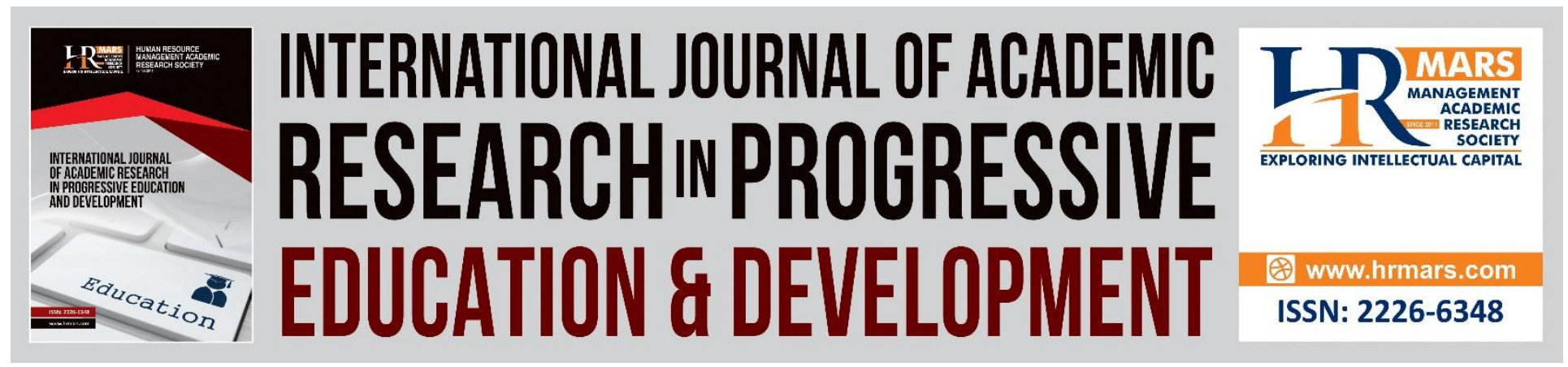

\title{
Service Learning in a Malaysian Undergraduate Tax Class
}

Sharon Cheuk, Esmie Nichol, Asri Marsidi, Sharifah Sabrina Syed Ali, Salawati Sahari, Shaharudin Jakpar, Michael Tinggi, Suzila Mohamed Yusof, Ahmad Syubaili Mohamed, Damien Lee and Joanne Janang

To Link this Article: http://dx.doi.org/10.6007/IJARPED/v9-i2/7963 DOI:10.6007/IJARPED/v9-i2/7963

Received: 02 June 2020, Revised: 29 June 2020, Accepted: 14 July 2020

Published Online: 27 July 2020

In-Text Citation: (Cheuk, et. al., 2020)

To Cite this Article: Cheuk, S., Nichol, E., Marsidi, A., Ali, S. S. S., Sahari, S., Jakpar, S., Tinggi, M., Yusof, S. M., Mohamed, A. S., Lee, D., and Janang, J. (2020). Service Learning in a Malaysian Undergraduate Tax Class. International Journal of Academic Research in Progressive Education \& Development. 9(2), 661-673.

Copyright: (C) 2020 The Author(s)

Published by Human Resource Management Academic Research Society (www.hrmars.com)

This article is published under the Creative Commons Attribution (CC BY 4.0) license. Anyone may reproduce, distribute, translate and create derivative works of this article (for both commercial and non-commercial purposes), subject to full attribution to the original publication and authors. The full terms of this license may be seen

at: http://creativecommons.org/licences/by/4.0/legalcode

Vol. 9(2) 2020, Pg. 661 - 673

http://hrmars.com/index.php/pages/detail/IJARPED

JOURNAL HOMEPAGE

Full Terms \& Conditions of access and use can be found at http://hrmars.com/index.php/pages/detail/publication-ethics 


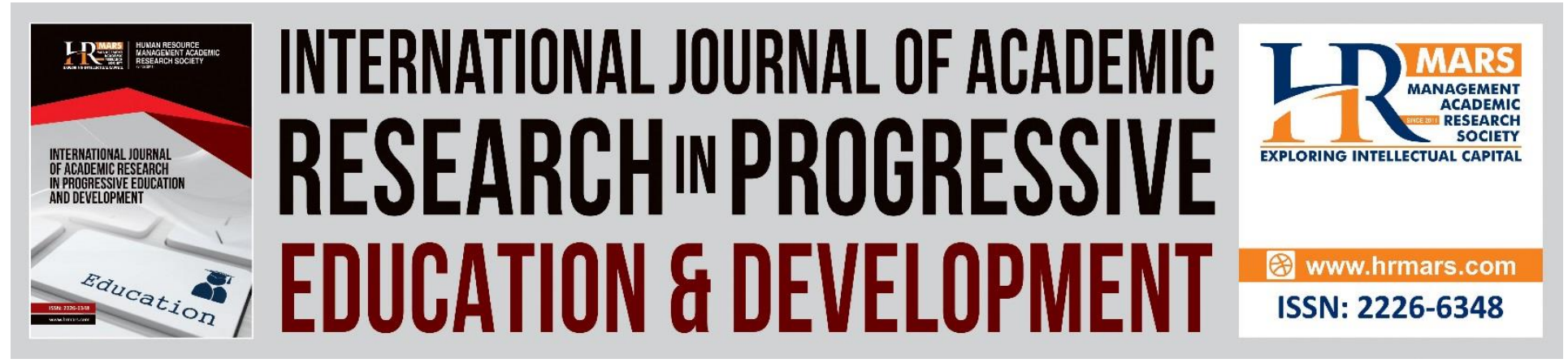

\title{
Service Learning in a Malaysian Undergraduate Tax Class
}

\author{
Sharon Cheuk, Esmie Nichol, Asri Marsidi, Sharifah Sabrina Syed \\ Ali, Salawati Sahari, Shaharudin Jakpar, Michael Tinggi, Suzila \\ Mohamed Yusof, Ahmad Syubaili Mohamed, Damien Lee and \\ Joanne Janang \\ Faculty of Economics and Business, Universiti Malaysia Sarawak, Malaysia
}

\begin{abstract}
Accounting programmes in Malaysian public universities have long been encouraged to utilise service-based learning as an educational tool to translate theory learnt in the classroom to practical application into a real-life scenario. This paper describes a service learning project that was adopted in a Malaysian undergraduate tax class, which involved the preparation of tax computation and the giving of tax advice to the clients derived from the local community. Students would document the details of the process in a report, and submit reflection journals on their experience. Student evaluation of this project is obtained via a survey; qualitative evaluation is obtained via reflection journals. Student perceptions of this project were largely positive, and the project was seen to contribute towards the course learning outcomes. Students also cited the following as outcomes experienced after the project: better appreciation of the real-world business setting, attainment of better communication, knowledge management and time management skills, better understanding of course content, increased confidence level, experience of a sense of responsibility to the community and the possibility of adopting the tax field as a future career choice.
\end{abstract}

Keywords: Service Learning, Taxation, Undergraduate, Malaysia.

\section{Introduction}

Education reforms in the accounting programmes in Malaysian public universities have long been touted. In 2015, the Hala Tuju 3 review report (Ministry of Higher Education, Malaysia, 2015) highlighted the need for accounting graduates to be well-equipped with technical and soft skills. Technical skills referred to technical knowledge of the International and Malaysian Financial Reporting Standards, International Standards on Auditing and tax law and regulations. The report further noted that employers gave low scores on students who interned at their respective firms in three areas: communication skills (verbal and written, especially in English), 
stress management and the use of technology in work. Communication skills included the ability to interact with important groups such as audit clients.

At the same time, the Malaysian Ministry of Higher Education in 2015 had issued the Education Blueprint 2015 - 2025 (Higher Education) which encouraged the use of service learning to develop $21^{\text {st }}$ century skills (Ministry of Higher Education Malaysia, 2015). In particular, service learning was made compulsory for every academic programme via a ministry directive.

Service learning is a "course-based, credit-bearing educational experience that allows students to (a) participate in an organized service activity that meets identified community needs and (b) reflect on the service activity in such a way as to gain further understanding of course content, a broader appreciation of the discipline, and an enhanced sense of civic responsibility" (Bringle and Hatcher, 1995, p. 112). As a result of the government directive, various university courses in Malaysia have attempted to adopt service learning, for instance in the disciplines of engineering (Mamat, Amran, Ismail, Ishak, Ibrahim and Baba, 2019), information technology (Musa, Abang Ibrahim, Abdullah, Saee, Ramli, Mat and Ahmad Khiri, 2017) and communications (Rodrigo and Tan, 2016). In the international context for the accounting discipline, service learning has been adopted in tax courses (Strupeck and Whitten, 2004; Calvert, Kurji and Kurji, 2011; Boneck, Barnes and Stillman, 2014; Poston and Smith, 2015), accounting information systems (Rose, Rose and Norman, 2005) and auditing (Laing, 2013), amongst others. To the authors' knowledge, service learning has not been adopted in any Malaysian accounting courses.

The higher rate of service learning adoption in tax courses, as can be seen by the greater amount of related literature, is most likely due to an existing programme in the US (Volunteer Income Tax Assistance or VITA) targeted to give free tax help to the lower income group, disabled persons and limited English speaking taxpayers; Inland Revenue Service-certified volunteers (students in this case) would offer the service. The service offered by student/volunteers would include tax return preparation and interview of taxpayers to determine if all income, deductions and allowable credits are claimed. Because the VITA programme is well-structured and there are ready-made tax clients, it is not difficult to adopt as part of a service learning approach in a university course.

There is no such programme in Malaysia, but such a concept could be adopted in the local context. This paper describes a service learning project carried out by students in an undergraduate tax course in Malaysia. The motivation for the project is to increase studentcentred and experiential learning and to translate theory into practical knowledge. To some extent, the work environment is simulated as students are able to participate in a realistic experience which adds value to their education. The experience include the preparation of tax returns, the conduct of client interviews, the recording of relevant information for tax purposes and the collection of supporting documentation. This experience closely mimics the actual work performed by a working tax associate. On top of that, students provide a free service to members of the community who need it.

\section{The Service-based Learning Project: Preparation and Instruction}

Students are requested to form themselves into groups of 2-3 and look for individual "clients" amongst the local community who need service in the preparation of personal tax computation. Students would then look for clients which have at least 2 tax sources (e.g. 
employment income, business income, investment income, rental income, etc) so that the resultant computation will be richer and more complex in content. Students would also need to advise the clients accordingly in terms of tax deadlines, retention of documents, and any other relevant tax advice. When presenting the assignment, students need to document the detailed work done in the form of a report. Evidences (supporting documentation) for the tax computation are attached as an appendix. Other than a detailed report, students are also required to document their thoughts on the assignment via a reflection journal. At the end of the project, students are asked to get an evaluation of the service given from the client. All project deliverables are assessed accordingly.

The project assignment is given to the students at the beginning of the semester so that students can form into groups early and approach potential clients who would agree to reveal their tax related information. It has to be noted that the rejection rate is high, for obvious reasons, and students may need to approach a few clients before one would give consent. Client name could be kept confidential, and if the clients chose anonymity, students would need to blank out the client names in all supporting documents that are presented as evidence for the tax computation.

Students were taught the tax principles needed to perform tax computation throughout the semester (14 weeks), in particular employment income, investment income, business taxation, personal tax reliefs available, income tax rates, and tax deadlines and penalties. They were expected to perform the actual tax computation towards the end of the semester.

The role of the course instructor is that of a facilitator/advisor. Students make appointments with the instructor to seek advice on client issues which could not be solved by themselves. The instructor has no direct contact with the client.

\section{Evaluation of Student Performance}

As mentioned earlier, project deliverables include a detailed project report, reflection journal and the client's assessment of the students' service.

The detailed project report is assessed for depth and accuracy of content, organisation, ability to define terms and jargon, use of language, use of appendices where appropriate, and visual format. For depth of content, the highest score would be given for an accurate and complete explanation of key concepts and theories, drawing on relevant literature. Also, enough detail is presented to allow the reader to understand the content and make judgments about it. In addition, applications of theory are included to illuminate issues and give insight to readers. For accuracy of content, high scores are given for consistently accurate information (such as names and facts). Score are also given for good organisation of the report, in which all key elements are present and structured in a standard manner, and there is progressive flow of ideas. Reports must define all technical terms and jargon accordingly to be highly rated. As for use of language, high scores are given for good word choice, use of grammar and sentence structure. Information should be appropriately placed in either the main text or an appendix; appendices are documented and referenced in the text. And finally, the report document itself should be visually appealing, with appropriate use of white space and colour to separate blocks of text and add emphasis, to enable the reader to navigate the document easily. 
The reflection journal is assessed on the student's description of application of course concepts to service learning, critical thinking, awareness of the purpose of the service rendered, responsibility to community, and impact on student's personal life. The first assesses whether the student uses the service experience to evaluate course concepts and his/her efficacy of service. The second item, critical thinking, assesses whether the student evaluates his/her perspectives, knowledge and opinions gained from both course concepts and service experience, and whether he/she links these assessments to his/her own perspectives and opinions. Next is the service learning component itself, and the student is assessed on whether he/she understands the complexity of the tax issues and solutions, and whether he/she is aware of his/her personal role in arriving at the solutions in delivering the service to the client. In terms of responsibility to the community (civic engagement), the student must also exhibit that he/she embodies a personal sense of responsibility to the community regarding issues pertinent to the service experience and actively participates in the collective effort to solve the said issues. Finally, under the impact on student's personal life, the student has to show that he/she uses changes in perspective to guide choices and behaviours in areas related to the service experience as well as in areas related to other social issues.

The client's assessment is based on the aspects of cooperation, communication, commitment, dependability, professionalism, attitude and assignment outcome. On cooperation, students are assessed whether they worked well together. On communication, the client rates whether the group communicated effectively with $\mathrm{him} / \mathrm{her}$ and with each other. The group was also assessed on their commitment to the assignment and whether they were able to deliver what was asked of them, which is related to dependability: whether they were reliable and could be depended on to deliver.

In terms of professionalism, students were assessed as to whether they behaved appropriately, and for attitude, whether they demonstrated a positive attitude towards the assignment. Finally, client assessed as to whether the assignment was successfully completed.

\section{Implementation of Project - Instructor Observations}

In general, the students were able to perform the project well. In terms of project management, students tended to divide roles within their groups; and some groups even took minutes for every meeting held. All groups managed to finish the project on time. Clients obtained ranged from staff in employment and small business operators (including a car workshop, restaurant operator).

However, from interactions between the instructor and students, some difficulties were

faced. By far the most prevalent difficulty faced by the students is that they were not able to obtain clients who agreed to reveal their tax matters. As a result, many of the students got their family members or friends to become their clients.

Some student groups found it difficult to find clients with more than two income sources (as required for the project); this could be due to limitations in their network of acquaintances, or the fact that they could not differentiate between source of income. For instance, some students were not aware that interest income from savings is a separate income source. Related to this issue, students also found themselves unable to classify the different sources of income. 
For instance, they were uncertain of the correct classification (and hence tax treatment) of sundry income or commission earned from sale of insurance policies.

Another difficulty noted was pertaining to supporting documents: either the client did not have sufficient documentary evidence as support for the tax items identified, or students were unclear as to the right supporting documents to obtain. For example, pertaining to rental income, possible supporting documents could be the rental agreement or official receipts issued for rental payments; rental expenses would be various property maintenance expenses, of which supporting documents would be the relevant invoices.

For employment income, a common issue amongst students was the interpretation of the salary slips obtained. In particular, they were not sure of the taxability of certain employment items such as civil service and cost of living allowances. Also, they were also unclear as to the exemptability of certain salary deductions.

For business income, some students noted that some clients did not prepare business financial statements, and therefore they had to draft the financial statements for the clients before drafting the tax computations.

\section{Students' Evaluation of Project}

Students were asked questions about their experience with the service learning project after their participation. For all questions, agreement was rated from 1 (strongly disagree) to 5 (strongly agree). A total of 78 students participated in this survey and the results are summarised in Table 1.

Table 1. Average rank of responses from survey on student perception of service learning project

\begin{tabular}{|l|c|}
\hline & $\begin{array}{c}\text { Average rank } \\
\text { (78 responses) }\end{array}$ \\
\hline $\begin{array}{l}\text { Doing this service project helped me to better connect to what I am learning in } \\
\text { my class. }\end{array}$ & 4.3 \\
\hline $\begin{array}{l}\text { Completing this service project improved my relationship with my classmates } \\
\text { and/or instructor. }\end{array}$ & 4.5 \\
\hline $\begin{array}{l}\text { After completing this service project, I have a better idea of what I want to do } \\
\text { with my life. }\end{array}$ & 4.1 \\
\hline $\begin{array}{l}\text { This service learning experience increased my understanding of problems or } \\
\text { challenges other people or groups face in society. }\end{array}$ & 4.3 \\
\hline I learned something new about my community through this experience. & 4.4 \\
\hline $\begin{array}{l}\text { My service project helped me to understand how my work would help make a } \\
\text { difference for others. }\end{array}$ & 4.3 \\
\hline I would recommend this service learning experience to other students. & 4.3 \\
\hline I wish my other courses include service learning opportunities. & 4.0 \\
\hline Every student should have to do a service learning project in order to graduate. & 4.1 \\
\hline
\end{tabular}

It can be noted that on average, students generally agreed with all the statements presented; the highest level of agreement can be seen for the statement "Completing this service project improved my relationship with my classmates and/or instructor". This could be due to 
the higher level of interaction within and outside the classroom environment, due to the need for the student groups to meet and discuss the project approach, and for the students to meet with the course instructor to obtain feedback and advice. The lowest level of agreement can be seen for the statement "I wish my other courses include service learning opportunities." This could be due to the amount of work required for the project, and the difficulty to obtain a client who would agree to reveal his/her tax information before project could even commence. More service learning projects in a student's portfolio would mean a bigger overall workload and it is understandable why students may not be too eager to take that on.

Students were also asked a series of questions before and after the course, pertaining to their achievement of course learning outcomes. The survey comprise 7 questions which were ranked using Likert scale, with rank 1 relating to Strongly Disagree $=1$ and Strongly Agree $=5$ (rank 3 refers to Neutral). The average rank of the responses are displayed in Table 2 below.

Table 2. Average rank of responses from entrance and exit surveys

\begin{tabular}{|l|c|c|c|}
\hline & $\begin{array}{c}\text { Entrance survey } \\
\text { average rank } \\
\text { (78 responses) }\end{array}$ & $\begin{array}{c}\text { Exit survey } \\
\text { average rank } \\
\text { (59 } \\
\text { responses) }\end{array}$ & $\begin{array}{c}\text { Increase in } \\
\text { average rank }\end{array}$ \\
\hline $\begin{array}{l}\text { I can differentiate between different } \\
\text { sources of income (individual, sole } \\
\text { proprietorship and business). }\end{array}$ & 3.3 & 4.4 & 1.1 \\
\hline $\begin{array}{l}\text { I am able to explain the rules of tax } \\
\text { residency in Malaysia. }\end{array}$ & 2.4 & 4.3 & 1.9 \\
\hline $\begin{array}{l}\text { I am able to determine whether an } \\
\text { individual is a tax-resident in Malaysia, } \\
\text { based on a given scenario. }\end{array}$ & 2.7 & 4.3 & 1.7 \\
\hline $\begin{array}{l}\text { I am able to prepare a tax computation for } \\
\text { an individual having different sources of } \\
\text { income. }\end{array}$ & 2.2 & 3.9 & 1.2 \\
\hline $\begin{array}{l}\text { I can compute and analyse capital } \\
\text { allowances for business. }\end{array}$ & 2.5 & 3.7 & 1.3 \\
\hline $\begin{array}{l}\text { I am able to translate sole proprietorships } \\
\text { and business profit and loss into tax } \\
\text { chargeability. }\end{array}$ & 2.4 & 3.7 & \\
\hline $\begin{array}{l}\text { I am able to explain the tax administration } \\
\text { rules and procedures in the context of } \\
\text { assessment, collection and appeal. }\end{array}$ & 2.3 & & \\
\hline
\end{tabular}

It can be seen that at the end of the course, the average rank of all the statements have increased by at least 1.1, which is a testament to the effectiveness of the project.

Students were also asked to describe in narrative form the impact their service learning experience had on their lives, through reflection journals. Data were analysed using the thematic approach. Their responses showed some common themes which are summarised in Table 3. 
INTERNATIONAL JOURNAL OF ACADEMIC RESEARCH IN PROGRESSIVE EDUCATION AND DEVELOPMENT

Vol. 9, No. 2, 2020, E-ISSN: $2226-6348$ @ 2020 HRMARS

Table 3. Key impacts of service learning experience on students

\begin{tabular}{|c|c|c|}
\hline & Key themes & Details \\
\hline 1 & Real life scenario/experience & $\begin{array}{l}\text { - Obtain first-hand knowledge of the business world } \\
\text { - Utilisation of skills in real-life setting } \\
\text { - Preparation of students for workforce }\end{array}$ \\
\hline 2 & Learnt better communication & $\begin{array}{l}\text { - Better communication with clients through } \\
\text { interviews conducted } \\
\text { - Better social skills through interaction with people } \\
\text { outside of normal circle/network } \\
\text { - Better communication with team members through } \\
\text { collaboration } \\
\text { - Better written communication skills through } \\
\text { documentation of interview findings in journal }\end{array}$ \\
\hline 3 & $\begin{array}{l}\text { Better knowledge and time } \\
\text { management skills }\end{array}$ & Learned to take a systematic approach towards work. \\
\hline 4 & $\begin{array}{l}\text { Better understanding of } \\
\text { course content }\end{array}$ & Through application of theory into a real-life scenario \\
\hline 5 & Increased confidence level & $\begin{array}{l}\text { Increased confidence level experienced as a result of } \\
\text { better communication and problem solving skills } \\
\text { developed in the project }\end{array}$ \\
\hline 6 & Future career & $\begin{array}{l}\text { Increased knowledge in what taxation work entails has } \\
\text { increased interest in this area as a potential future } \\
\text { career }\end{array}$ \\
\hline 7 & Responsibility to community & $\begin{array}{l}\text { - To teach the community, who have low tax } \\
\text { awareness, to prepare their own tax computation } \\
\text { using the Inland Revenue Board (IRB) e-filing system } \\
\text { - To help community be aware of tax deductions, } \\
\text { rebates and reliefs that can be claimed } \\
\text { - To give advice on potential tax savings } \\
\text { - To be accurate in preparing the tax computation for } \\
\text { the client, to avoid over/under payment of tax and } \\
\text { - ensure no penalties } \\
\text { - To teach community on how to keep documents } \\
\text { related to tax in case of future tax audit } \\
\text { Maintain client confidentiality }\end{array}$ \\
\hline
\end{tabular}

The findings revealed 7 main themes representing the outcomes of the project as perceived by the students. A significant number of responses noted that the project translated theoretical knowledge to a practical scenario, giving them hands-on experience and enabling them to utilise their skills in a real-world setting. In their opinion, this in turn prepared them for their workforce in the future. This is illustrated in the following responses: 
"...I practised the theory learned in class ..... some students need real life applications to learn something well" (Respondent 15)

"...this service-learning assignment allowed us to seek opportunities to obtain first-hand knowledge of business world and practice environment where we utilize those skills in reallife setting. Through the experience that I have gained in accomplishing this assignment, it also helped me to gain further understanding of course content, a broader appreciation of the discipline and enhanced sense of civic responsibility where it opened my eyes to ways that I can help people with the skills I have obtained from my education" (Respondent 7)

"Since helping people is fun to me, I am able to obtain a good experience....it makes me feel interested and I am excited to keep learning taxation down the road." (Respondent 46)

"I made more academic progress by participating in this project compared to other subjects studied in a classroom setting. The hands-on experience helped me learn effectively and efficiently". (Respondent 41)

The second key theme is communication skills, where students noted that they improved in communication abilities overall as a result of this project. They noted that the improvement was experienced in the following aspects. Firstly, with their respective clients, as a result of interviews conducted to elicit tax-relevant information; secondly, as clients can be strangers (initially), their social skills are improved as they interacted with people from outside the students' networks. In performing the assignment as a group, work collaboration improved team communication and communication with the course instructor is also improved as the team sought advice and consultation on technical matters and issues encountered. Finally, written communication is also improved as all project findings needed to be documented accordingly, either in interview transcripts and/or minutes of meetings. These are illustrated in the following responses:

"I've learnt how to improve my social skills and how to communicate with the client and $i$ believe that this is very useful during my working life". (Respondent 34)

"...improved my social skills as I got to interact with people outside my class". (Respondent 16)

"...improved in my interviewing skills.... understood the need to approach our client in a formal manner. At the end of the day, I increased in confidence in interacting with unfamiliar individuals". (Respondent 44)

"...this assignment helped me to improve communication skills and my relationship with coursemates and others". (Respondent 32)

"My communication skills increased through interviewing clients and taking notes on all proceedings..." (Respondent 25)

The third key theme refers to gaining better knowledge management skills as a result of the process of the preparation of tax computation. Such skills involve being more systematic on the organisation of information, and taking care to be accurate in the presentation of information. These are illustrated in the following responses: 
"I have become a more systematic person as a result of the tax computation preparation - errors are reduced and easier for me to check the tax computation when I am more systematic." (Respondent 30)

"I've learnt to become more prudent as during the tax computation exercise there was a need to take note of information and organise/categorise them in the correct section. Also, each piece of information needed to be supported by relevant document/evidence. I have also become more observant to take note of detailed information." (Respondent 31)

The fourth theme pertains to better understanding of the course content after the project was completed, through the application of theory to a practical scenario. As a few students stated:

"This assignment offered exposure to the kind of work patterns that I'll encounter in my future career and provided me with a hands-on learning experience that most other classes do not provide". (Respondent 7)

"...indirectly helped us prepare for our exam.." (Respondent 16)

"I can apply what I learned in class in a real situation such as the computation of the client's tax which requires us to collect and compile all documents related to the client's income". (Respondent 1)

".... get to understand the concepts on a deeper level". (Respondent 4)

"The journey of service learning project was amazing for me. This project really helped me to understand more about taxation rule and regulations in Malaysia and the most important thing is to apply what we learn in class into a real life situation. This experience was able to enhance my understanding. Therefore, I really recommend that each course should have one service learning project instead of being exam oriented". (Respondent 38)

The fifth theme as found from the responses referred to an increased confidence level in own skills at the completion of the project. As cited by some students:

"...at first when $i$ entered the class, i was told that we will have to help others to compute their tax. $i$ was shocked because i have totally no idea on how to do it.... however, at the end of the semester, im proud that $i$ can do this (Respondent 8).

"This type of practice helped me gain more knowledge and improved my skills too..." (Respondent 42)

"From this service learning experience, I feel capable to help others by applying what I have learnt in class.... can now distinguish between the sources of income and classify them according when computing the chargeable income of my client." (Respondent 46)

"I have more confidence now in helping my family members and friends to do their tax computation and to give advice". (Respondent 52)

The next major theme pertains to the students' exposure to a potential future career in the tax field. In other words, through this service learning assignment, some students better understood how a tax professional would work, and thought it could be their future career. As stated by some students: 
"this assignment is a stepping stone for my future working environment and has helped me become a better person". (Respondent 31)

"...it helped shaped me into a future accountant". (Respondent 23)

"By doing tax computation for others, i have a rough idea on what working in a tax department would be like and it helps me to decide whether to work in the tax field in future." (Respondent 36)

Finally, students cited a sense of responsibility to the community as a result of the project. They felt a responsibility to educate the community, who had low tax awareness, to prepare their own tax computation, specifically using the Inland Revenue Board (IRB) e-filing system. In the process of community education, they would be made aware of the available tax deductions, rebates and reliefs that can be claimed. Students also felt responsible to give advice on potential tax savings, and to ensure accuracy in the final tax computation to avoid over/under payment of tax and no penalties. Advice on proper document retention in case of future tax audit was also considered important. Finally, the students felt responsible over the need to maintain client confidentiality in not revealing client information to others, as is required under accountancy professional ethics. As stated by some students:

"We educated client on the tax computation process so that she is able to do it herself in the future". (Respondent 33)

"We assisted with the client's tax computation to help him know the correct tax payable to avoid being penalised. We also wanted to help the community be aware of tax deductions, rebates and reliefs that can be claimed, as well as whether to opt for separate or joint assessment". (Respondent 14)

"It is important to maintain client confidentiality - revealing client information may affect client's reputation and be detrimental if information falls into the wrong hands". (Respondent 45)

\section{Conclusion}

In conclusion, the service learning project as described in this paper contribute positively to the achievement of course learning outcomes, where students are in a position to realise and learn a lot of things on their own without the need to be explicitly taught. It also enhances the professional skills of accounting students, in particular enhanced communication and interviewing skills, and knowledge management and time management skills. Students achieved a more practical understanding of taxation concepts and have become more competent in using the e-filing website through the experience of having to learn it well before teaching their clients. Students take away from the experience with strengthened competencies, they also have a greater level of confidence, some to the extent of seriously considering the tax field as their future career choice. In terms of service to the community, students have developed a greater sense of responsibility in the need to educate community on tax matters as well to give relevant tax advice. As a result, students are better prepared for the workforce. Simultaneously, through this project the university is able to realise its mission to service the community, in line with the directive of the Malaysian Ministry of Education. In conclusion, the service-based learning 
INTERNATIONAL JOURNAL OF ACADEMIC RESEARCH IN PROGRESSIVE EDUCATION AND

DEVELOPMENT

Vol. 9, No. 2, 2020, E-ISSN: $2226-6348$ @ 2020 HRMARS

project is an effectual and powerful teaching tool which delivers value to the student, the university, and the community at large.

\section{Acknowledgement}

This study was wholly funded via the Scholarship of Teaching and Learning Grant SoTL(A)/FEP/2019(2)/019 from Universiti Malaysia Sarawak (UNIMAS).

\section{Corresponding Author}

Sharon Cheuk, Universiti Malaysia Sarawak, Malaysia, Email: ccssharon@unimas.my.

\section{References}

Boneck, R., Barnes, J. N., and Stillman, T. F. (2014). VITA Experiential, Service-Learning, Learned Competencies, and Changed Mindsets. Journal of College Teaching \& Learning, 11(2), $71-$ 84.

Bringle, R., \& Hatcher, J. (1995). A service learning curriculum for faculty. Michigan Journal of Community Service Learning, 2, 112-122.

Calvert, V., Kurji, R., and Kurji, S. (2011). Service learning for accounting students: what is the faculty role? Research in Higher Education Journal, 10. Retrieved from https://www.aabri.com/manuscripts/10513.pdf.

Laing, G. K. (2013). Service Learning: An Auditing Project Study. International Education Studies, 6(1), 174-183.

Mamat, M., Amran, N., Ismail, Z., Ishak, H., Ibrahim, M., and Baba, S. (2019). Service-Learning in Malaysia: Practice and Implementation in Four Public Universties. International Journal of Civil Engineering and Technology, 10, 1632-1639.

Ministry of Education Malaysia (2015). Malaysia Education Blueprint 2015 - 2025 (Higher Education). Malaysia: Ministry of Education.

Ministry of Higher Education, Malaysia. (2015). Malaysian Higher Education Institution Accounting Program Review Report 2013. Malaysia: Ministry of Higher Education.

Musa, N., Ibrahim, A. D. H., Abdullah, J., Saee, S., Ramli, F., Mat, A. R., Khiri, A. M. J. (2017). A Methodology for Implementation of Service Learning in Higher Education Institution: A case study from Faculty of Computer Science and Information Technology, UNIMAS. Journal of Telecommunication, Electronic and Computer Engineering, 9(2-10). Retrieved from https://journal.utem.edu.my/index.php/jtec/article/view/2712/1759

Poston, K. M., and Smith, R. A. (2015). An Interdisciplinary Service-learning Course for Undergraduate Finance and Accounting Students: The VITA Program Expanded. Journal of Financial Education, 41(1), 1-31

Rodrigo, R., and Tan, W. C. (2016). Impacts of service learning on achieving learning outcomes in a university course. Malaysian Journal of Industrial Technology, 1(2), 25-31.

Rose, J., Rose, A., \& Norman, C. S. (2005). A Service-Learning Course in Accounting Information Systems. Journal of Information Systems, 19(2), 145-172.

Still, K., \& Clayton, P. (2004). Utilizing Service-Learning in Accounting Programs. Issues in Accounting Education, 19, 469-486. 
INTERNATIONAL JOURNAL OF ACADEMIC RESEARCH IN PROGRESSIVE EDUCATION AND

DEVELOPMENT

Vol. 9, No. 2, 2020, E-ISSN: 2226-6348 @ 2020 HRMARS

Strupeck, C. D., and Whitten, D. (2004) Accounting service-learning experiences and the IRS volunteer income tax assistance programme: a teaching note, Accounting Education, 13(1), 101-112.

Strupeck, C. D., and Whitten, D. (2004) Accounting service-learning experiences and the IRS volunteer income tax assistance programme: a teaching note, Accounting Education, 13(1), 101-112. 